\title{
MYELOMATOSIS WITH EXTENSIVE PULMONARY INVOLVEMENT
}

\author{
BY \\ ZELMAN FREEMAN \\ From the Eastern Suburbs Hospital, Sydney, N.S.W.
}

(RECEIVED FOR PUBLICATION FEBRUARY 14, 1961)

This patient had a plasma cell myeloma, infiltrating the lung in a lobar manner, without obvious osseous involvement, and simultaneously showing Bence-Jones protein in the urine and an abnormal globulin content of the blood. The extensive pulmonary involvement is unusual.

\section{Case Report}

A woman, aged 75 years, was admitted to the Eastern Suburbs Hospital for investigation of loss of weight and strength, occurring over the previous 12 months, which followed an attack of "pneumonia" a year before. She had no cough or sputum, no bone pain or history of fractures, and apart from generalized weakness and anorexia had no complaints.

She was a frail patient with some purpuric spots on the forearms. She was pale but had no lymph node enlargement or abdominal masses. There was no sputum for examination, and at no time during her six weeks' stay in hospital was there any fever. Radiography of the lungs (Figs. 1 and 2) showed a left-sided opacity which was confined to the upper lobe and sharply demarcated by the interlobar fissure. This was described as consolidation, ? inflammatory in origin, and a right basal shadow was also noted. Radiographs of the skull, spine, and long bones revealed no abnormality, apart from well-marked degenerative spondylosis in the lumbar region.

The Mantoux test $(1$ in 1,000$)$ was negative. Haemoglobin was $9.2 \mathrm{~g} . / 100 \mathrm{ml}$., white cell count $8,300 /$ c.mm. (neutrophils $70 \%$, lymphocytes $23 \%$, eosinophils $2 \%$, monocytes $5 \%$ ). The E.S.R. was 50 $\mathrm{mm}$. (maximum with micro method). The blood urea level was $134 \mathrm{mg} . / 100 \mathrm{ml}$. The serum alkaline phosphatase level was $4.5 \mathrm{~K}$.-A. units. Serum electrophoresis (Fig. 3) showed total protein $9.36 \mathrm{~g} . / 100 \mathrm{ml}$. ; albumin $3.61 \mathrm{~g}$. $/ 100 \mathrm{ml}$.; $\alpha_{1}$-globulin $0.61 \mathrm{~g}$. $/ 100 \mathrm{ml}$., $\alpha_{2}$-globulin $0.56 \mathrm{~g} . / 100 \mathrm{ml}$., $\beta$-globulin $0.65 \mathrm{~g} . / 100 \mathrm{ml}$., and $\gamma$-globulin $3.93 \mathrm{~g} . / 100 \mathrm{ml}$.

There was Bence-Jones protein in the urine, and urine analysis showed a heavy cloud of albumin and no other abnormal constituents.

Liver function tests gave thymol turbidity as $\mathbf{5}$ units and serum bilirubin as $0.4 \mathrm{mg}$. \%.

A bronchoscopic examination was normal.

Marrow puncture showed $6 \%$ plasma cells.
A provisional diagnosis of multiple myeloma was made, though no conclusion was reached about the pulmonary findings. The patient died eight weeks after admission, and I am indebted to Dr. C. K. Lindsell for the following necropsy report.

The right lower lobe and left upper lobe of the lungs contained irregular areas of consolidation of almost gelatinous consistency. No evidence of tumour could be found in the bronchi or mediastinum.

The kidneys were granular and contracted. Microscopic examination of the lungs (Figs. 4 and 5) showed a diffuse infiltration by plasma cells and some deposits of protein in the areas of consolidation. There was no pathological change in the liver, but the kidneys showed interstitial fibrosis and some large casts in some of the tubules. Sections from the ilium revealed a slight increase in the number of plasma cells.

\section{Discussion}

Tumours of the plasma cells are of three kinds : (1) Plasma cell myelomatosis, (2) solitary plasmacytoma of the bone, and (3) primary plasmacytoma of soft tissues. The latter are differentiated from plasma cell granuloma by being composed solely of plasma cells with supporting fibrovascular stroma, and secondly having no admixture of other types of inflammatory cells.

Multiple myeloma is not a rare disease, and Meacham (1953) defines it as a malignant disease characterized by diffuse involvement of the osseous system with the production of bone pain, pathological fractures, and associated occasionally with Bence-Jones proteinuria. Others have enlarged the picture to include an almost constant renal involvement, anaemia, and the presence of an abnormal globulin in the blood. Moreover, it has been pointed out that osseous involvement may not be detected radiographically, and that sometimes the typical punched-out areas are replaced by diffuse osteoporosis and other confusing pictures.

Extramedullary myelomatous deposits were looked for in 40 cases of multiple myeloma by 


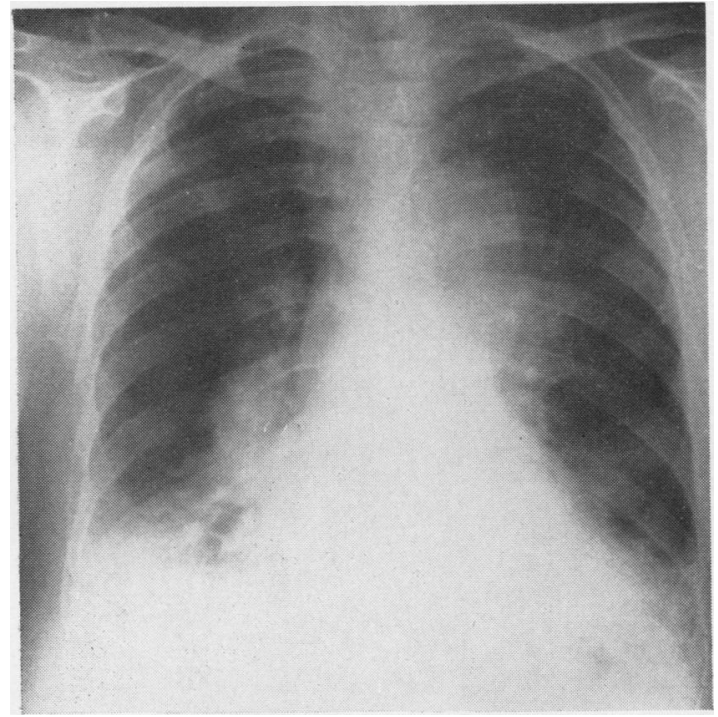

Fio. 1

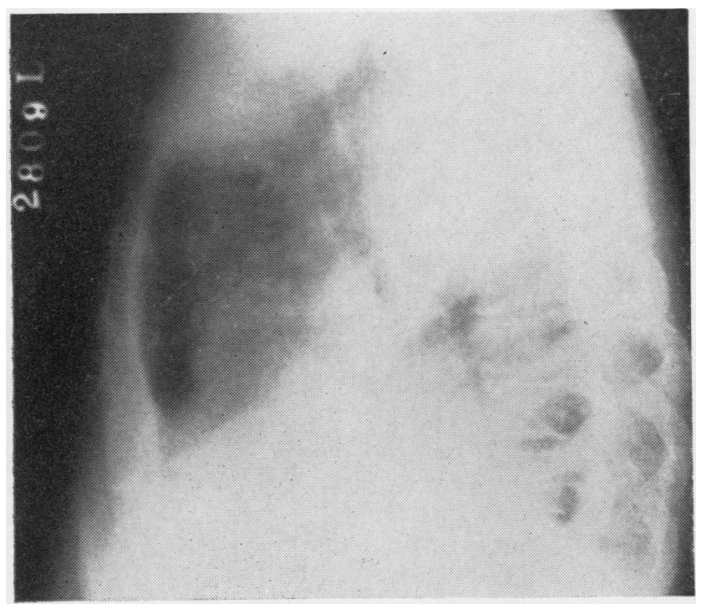

Fio. 2

Figs. 1 and 2.-Antero-posterior and lateral radiographs showing a left-sided opacity confined to the upper lobe and demarcated by the interlobar fissure.

Batts (1939) and in six out of the 11 necropsy cases some soft tissue involvement was present, but only in one patient were lung metastases detected radiologically.

Hellwig (1943) collected a series of 127 extramedullary plasma cell tumours, and, of these, 64 were associated with the upper air passages but none were described as infiltrating the lung. Gordon and Walker (1944) presented the first case of a small plasmacytoma of the lung which was encapsulated and was not infiltrating. Radio-

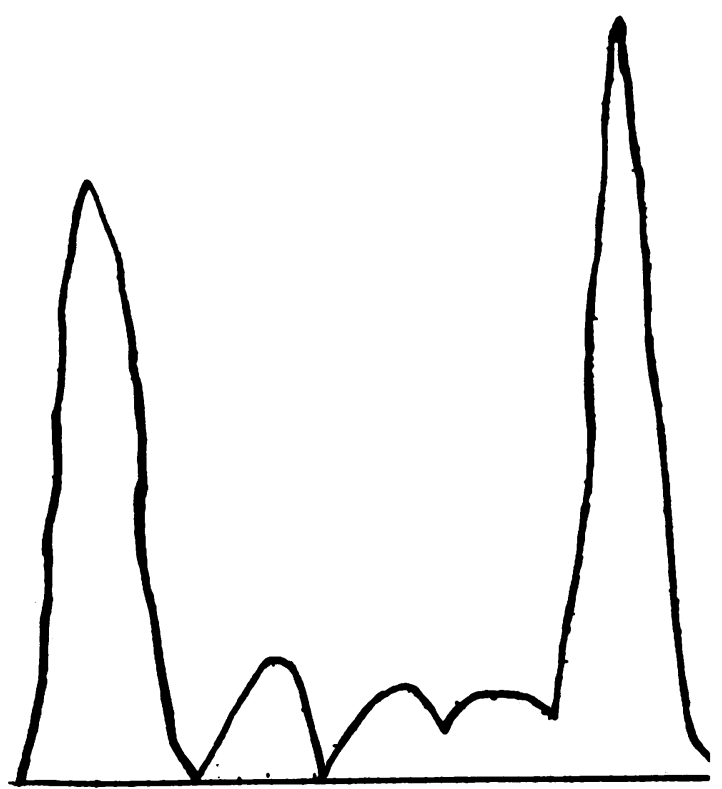

FIG. 3.-Electrophoretic pattern of serum (see page 378 for serum protein analysis).

graphs of the bones did not reveal osseous lesions and there was no Bence-Jones protein in the urine. In 1947, Lichtenstein and Jaffe could find only five references to cases of metastases to the lungs in multiple myeloma. Dolin and Dewar in 1956 surveyed the literature and carried the total of reported cases of extramedullary plasmacytoma to 161 , and of these 121 were in the upper respiratory tract; of the remainder only two were in the lung.

In a monograph on the subject of multiple myeloma Snapper (1957) emphasizes the predilection for the upper respiratory passages of extraosseous myelomata, and remarks that, whereas they mostly remained as localized tumours, occasionally they were invasive. Bence-Jones protein in the urine, according to Snapper, had never been reported in such a case of extramedullary plasmacytoma without skeletal involvement. Pleural involvement is described but only when occurring secondarily to plasmacytomatous invasion of ribs or sternum, and in a report of 51 cases Meacham (1953) found no instance of isolated pleural involvement without an underlying bony lesion.

In a very full review of the subject Greene (1956) discusses pulmonary complications of multiple myeloma and attributes them to the low antibody content of the serum. This phenomenon is also observed in cases of macroglobulinaemia and leukaemia, where abnormal proteins in or near the globulin fraction of the serum may 


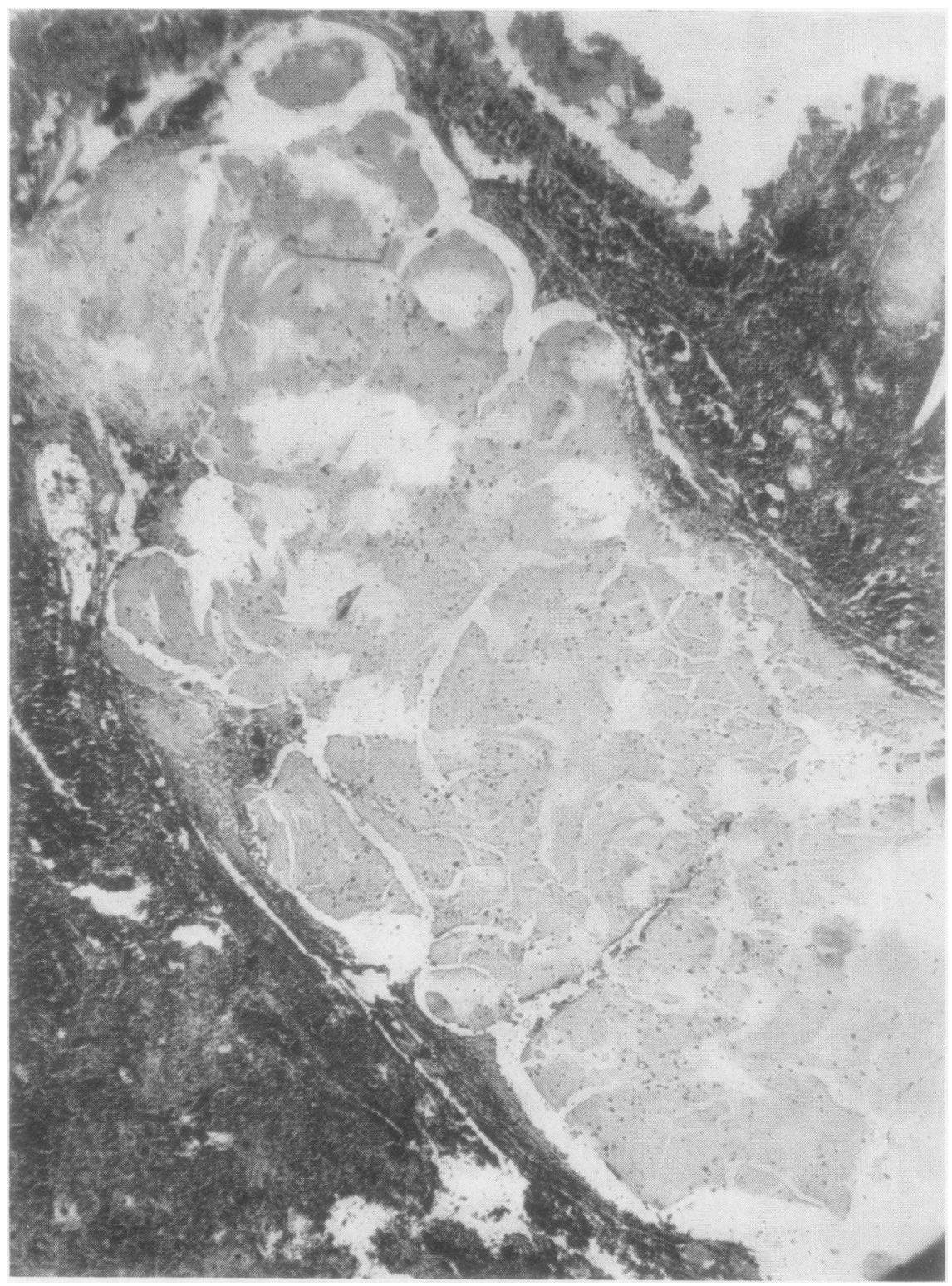

FIG. 4.-Low-power view of lung showing eosinophilic staining material.

suppress the natural formation of gamma globulin and lead to an increased susceptibility to infection. In a series of 57 cases of multiple myeloma Kenny and Moloney (1957) found no symptoms referable to the respiratory tract except those resulting from infection. Kennedy and Kneafsey (1959) describe two further cases of upper respiratory tract involvement by extramedullary plasmacytomas without invasion of the lung.
Favis, Kerman, and Schildecker (1960) described pleuropulmonary involvement as a dominant feature radiologically with parenchymatous invasion of one lung by a plasmacytoma, without evidence of bony thoracic cage involvement. However, there was clear evidence of generalized osseous involvement and other features, including sternal puncture, corroborated the diagnosis. There was no Bence-Jones protein in the urine. 


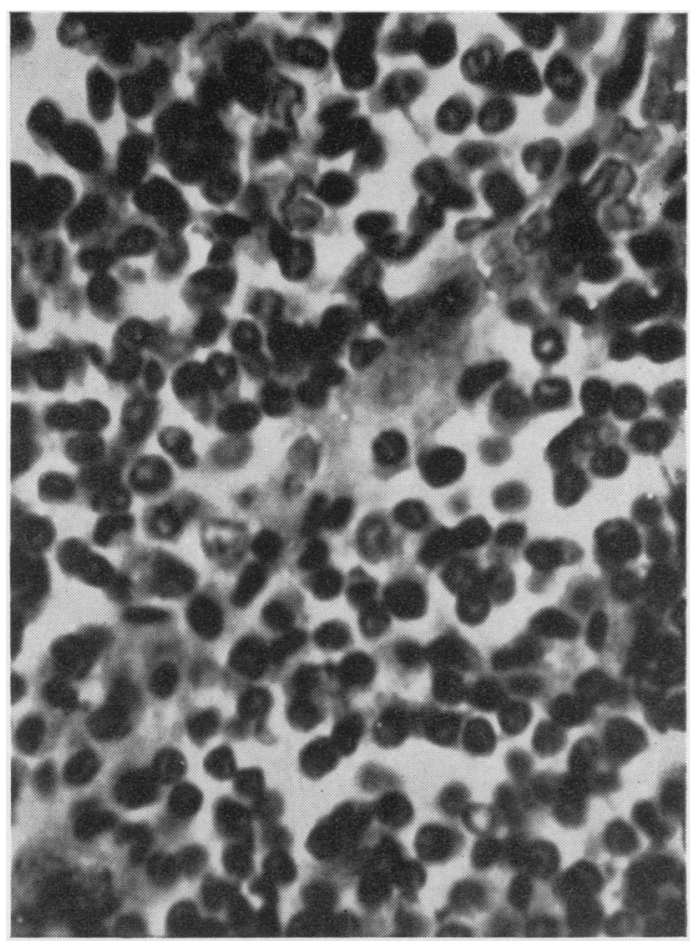

FIG. 5.-High-power view of lung showing myeloma cells.

There appears to be sufficient evidence here to diagnose myelomatosis, because there was a markedly raised gamma globulin fraction in the blood, Bence-Jones protein in the urine, a highly raised B.S.R., and evidence of renal impairment. At necropsy the picture of a "myeloma kidney" consisted of tubules plugged with an eosinophilic staining material, which is suggestive of myeloma though not diagnostic. Finally there is the picture of infiltration of the lung by masses of plasma cells which appear only with supporting fibrovascular stroma and in most areas appear to be unmixed with other inflammatory cells.

Although bony involvement could have been present, there was no radiological evidence of it and two marrow samples at different sites showed a non-diagnostic number of plasma cells. In view of the necropsy finding of gelatinous material in the large tumour areas of the left lung (Fig. 4), it is possible that the abnormal blood and urinary proteins originated from these rather extensive tumour sites, as the plasma cell is considered to be one source of gamma globulin.

\section{SUMMARY}

A case is described in which there was a lobar infiltration of the left lung and the base of the right lung with myelomatous tissue interspersed with a gelatinous eosinophilic staining material. This was associated with an abnormal level of globulin in the blood and Bence-Jones protein in the urine, though two marrow examinations, one from the sternum and one from the iliac crest, as well as many radiographs, failed to demonstrate bony involvement.

\section{REFERENCES}

Batts, M., Jr. (1939). Arch. Surg. (Chicago), 39, 807.

Dolin, S., and Dewar, J. P. (1956). Amer. J. Path., 32, 83.

Favis, E. A., Kerman, H. D., and Schildecker, W. (1960). Amer. J. Med., 28, 323.

Gordon, J., and Walker, G. (1944). Arch. Path. (Chicago), 37, 222.

Greene, L. (1956). Med. Tms (N.Y.), \&4, 1205.

Hellwig, C. A. (1943). Arch. Path. (Chicago), 36, 95.

Kennedy, J. D., and Kneafsey, D. V. (1959). Thorax, 14, 353.

Kenny, J. J., and Moloney, W. C. (1957). Ann. intern. Med., 46, 1079.

Lichtenstein, L., and Jaffe, H. L. (1947). Arch. Path. (Chicago), 44, 207.

Meacham, G. C. (1953). Ann. intern. Med., 38, 1035.

Snapper, I. (1957). Bone Diseases i, Medical Practice. Grune and Stratton, New York. 